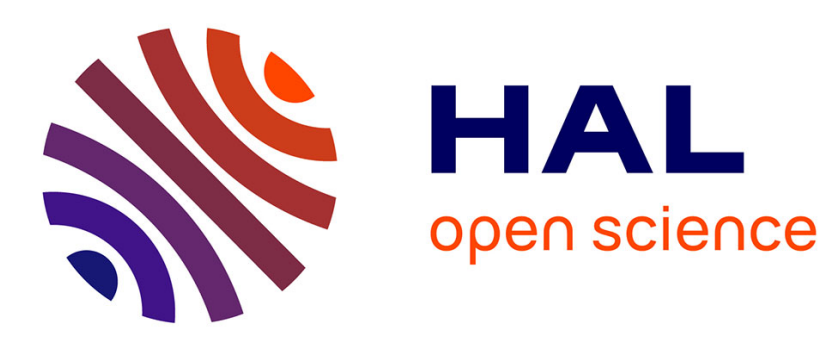

\title{
Banking Crises and Short and Medium Term Output Losses in Developing Countries: The Role of Structural and Policy Variables
}

Davide Furceri, Aleksandra Zdzienicka-Durand

\section{- To cite this version:}

Davide Furceri, Aleksandra Zdzienicka-Durand. Banking Crises and Short and Medium Term Output Losses in Developing Countries: The Role of Structural and Policy Variables. 2010. halshs-00491089

\section{HAL Id: halshs-00491089 \\ https://shs.hal.science/halshs-00491089}

Submitted on 10 Jun 2010

HAL is a multi-disciplinary open access archive for the deposit and dissemination of scientific research documents, whether they are published or not. The documents may come from teaching and research institutions in France or abroad, or from public or private research centers.
L'archive ouverte pluridisciplinaire HAL, est destinée au dépôt et à la diffusion de documents scientifiques de niveau recherche, publiés ou non, émanant des établissements d'enseignement et de recherche français ou étrangers, des laboratoires publics ou privés. 
Banking Crises and Short and Medium Term Output Losses in Developing Countries: The Role of Structural and Policy Variables

Davide Furceri, Aleksandra Zdzienicka

Juin 2010 


\section{GATE Groupe d'Analyse et de Théorie Économique Lyon-St Étienne}

93, chemin des Mouilles 69130 Ecully - France

Tel. +33(0)4 72866060

Fax $+33(0) 472866090$

6, rue Basse des Rives 42023 Saint-Etienne cedex 02 - France

Tel. +33 (0)4 77421960

Fax. $+33(0) 477421950$

Messagerie électronique / Email : gate@gate.cnrs.fr

Téléchargement / Download : http://www.gate.cnrs.fr - Publications / Working Papers 


\title{
Banking Crises and Short and Medium Term Output Losses in Developing Countries: The Role of Structural and Policy Variables ${ }^{1}$
}

\author{
Davide Furceri \\ OECD and University of Palermo \\ Aleksandra Zdzienicka \\ GATE Lyon - Saint-Etienne, Université de Lyon
}

\begin{abstract}
The aim of this work is to assess the short and medium term impact of banking crises on developing economies. Using an unbalanced panel of 159 countries from 1970 to 2006, the paper shows that banking crises produce significant output losses, both in the short and in the medium term. The effect depends on structural and policy variables. Output losses are larger for relatively more wealthy economies, characterized by a higher level of financial deepening and larger current account imbalances. Flexible exchange rates, fiscal and monetary policy have been found to be efficient tools to attenuate the effect of the crises. Among banking intervention policies, liquidity support resulted to be the one associated with lower output losses.
\end{abstract}

Keywords: Output Losses, Financial Crisis.

JEL: G1, E6

\footnotetext{
${ }^{1}$ We would like to thank Edmund Amann, Graciela Kaminski, David Lawson and other participants to the ESRC Development Economics Conference, Manchester (2010). The views expressed in this paper are those of the authors and do not necessarily represent those of the OECD or its member countries.

Mailing address: OECD, 2 rue André-Pascal, 75775 Paris CEDEX 16, Email: davide.furceri@ oecd.org.

Mailing address: Université de Lyon, Université Lyon 2, F-69007, Lyon, France. CNRS, GATE Lyon-St Etienne, UMR 5824, F-69130 Ecully, France, Email:. azdzieni@ens.lsh.fr.
} 


\section{Introduction}

The economic repercussions of the ongoing financial crisis has brought once again the discussions about the impact of banking crises on the real economy. While only few studies report a modest or insignificant effect (Hutchison, 2001), banking crises are in general associated with severe and long-lasting economic downturns, especially in developing economies (Hutchison and Ilan, 2005; Dell'Ariccia et al., 2008; Reinhart and Rogoff, 2009). ${ }^{2}$

The reason because banking crises have larger and more persistent effects in developing economies is because these countries are more vulnerable to the factors that generally lead to banking turbulences and that amplify their impact, such as: banks and private agents exposure to currency and maturity mismatch, disruption in international capital markets, banks panic (Chang and Velasco, 1999) and "sudden stops" in capital inflows (Calvo, 2006).

The main objective of this work is to provide new evidence of the effects of banking crises in developing countries, analyzing whether eventual output losses are permanent or if they are reverted in the medium term. The work also analyzes the role of structural and policy variables in affecting output losses.

In doing so, we follow a recent new empirical methodology, initially proposed by Jorda (2005) and used by Teulligns and Zubanov (2009), which consists of estimating impulse response functions (IRFs) of real output to banking crises dummies directly from local projections. This method completes previous attempts to measure the output cost of the crises, by

\footnotetext{
${ }^{2}$ For example, Hutchison and Ilan (2005) analyzing the impact of currency and banking crises on real output for a large set of countries find that while in a sample of 24 emerging economies the effect is about 8 percent and lasts 2 years, for developed countries the effect is about 2 percent during only one year. Similarly, Dell'Ariccia et al. (2008) find that the real effect of banking crises is about 1.5 percentage point bigger for developing countries. Moreover, the recent Reinhart and Rogoff's (2009) historical analysis underlines that a decline in real GDP is greater and more persistent for emerging than developed countries.
} 
assessing both the short and medium term impact. Indeed, while several works have focused on output losses in the short term, only few works have assessed the dynamic pattern of output following a banking crisis.

Using an unbalanced panel of 159 countries from 1970 to 2006, the paper shows that banking crises produce significant output losses, which are not reverted in the medium term. The magnitude of the effect depends on countries structural variables, and on the policy response that countries adopted to attenuate the effect of the crises. In particular, we find that output losses are larger for relatively more wealthy economies, characterized by a higher level of financial deepening and larger current account imbalances. Flexible exchange rates, fiscal and monetary policy have been found to be efficient tools to attenuate the effect of the crises, while among banking intervention policies, liquidity support resulted to be the one associated with lower output losses.

The rest of the paper is organized as follows. Section 2 describes the empirical methodology. Section 3 presents the results, and Section 4 concludes.

\section{Empirical Methodology}

In order to estimate the dynamic impact of banking crises episodes on the real output, we follow the method proposed by Jorda (2005) and Teuling and Zubaonov (2009). The approach consists of estimating impulse response functions (IRFs) directly from local projections. In detail, for each future period $k$ the following equation has been estimated:

$y_{i, t+k}-y_{i, t}=\alpha_{i}^{k}+\sum_{j=1}^{l} \gamma_{j}^{k} \Delta y_{i, t-j}+\beta_{k} D_{i, t}+\varepsilon_{i, t}^{k}$

with $k=1, . .8$. Where $y$ indicates the (log of) real output, $D$ is a dummy that takes the value equal to 1 in correspondence of the occurrence of a banking crisis, $\alpha_{i}$ represent country fixed effects, 
$\gamma_{j}$ captures the persistence of real output growth and $\beta_{k}$ measures the impact of banking crises on the change of (the log of) the real output for each future period $k$. Impulse response functions (IRFs) are then obtained by plotting the estimated $\beta_{k}$ for $k=0,1, . .8$.

An alternative way of estimating the dynamic impact of banking crises on output is to estimate an ARDL equation of output and crises dummies and to compute IRFs from the estimated coefficients. ${ }^{3}$ However, the IRFs derived using this approach are sensitive to the choice of the number of lags, and the inclusion of interaction terms in the equation can easily increase multicollinearity, making thus the IRFs unstable. In addition, the significance of longlasting effects on output with ARDL models can be simply driven by the use of one-type shock models (Cai and Den Haan, 2009).

In contrast, the approach used in this paper does not suffer from these problems since the lags of changes in real output enter only as control and are not used to derive the IRFs, and since the structure of the equation does not impose any permanent effects. Finally, confidence bands associated to the estimated IRFs are easily computed using the standard deviations associated to the estimated coefficients $\beta_{k}$, and Monte-Carlo simulations are not required.

To assess the impact of structural and policy variables on shaping the effect of banking crises on the real output, equation (1) is augmented by including these variables as control and as interaction term with the crises dummy. In detail, the following equation has been estimated:

$y_{i, t+k}-y_{i, t}=\alpha_{i}^{k}+\sum_{j=1}^{l} \gamma_{j}^{k} \Delta y_{i, t-j}+\beta_{k} D_{i, t}+\vartheta^{k} X_{i, t}+\delta^{k}\left(X_{i, t}-\bar{X}\right) D_{i, t}+\varepsilon_{i, t}^{k}$

\footnotetext{
${ }^{3}$ This approach was initially proposed by Romer and Romer (1989) and then recently applied by Cerra and Saxena (2008), Furceri and Mourougane (2009) and Furceri and Zdzienicka (2010) to assess the impact of financial crises on economic activity.
} 
where $X$ is a set of structural and policy variables including ${ }^{4}$ i) Country size (both in terms of population and GDP), ii) Trade openness; iii) Real GDP per capita; iv) Financial deepening (approximated by the ratio of private credit to GDP); v) Current account balances (as percent of GDP); vi) A measure of discretionary fiscal policy; vii) and of monetary policy, and viii) exchange rate regimes.

The interaction terms $\left(X_{i, t}-\bar{X}\right) D_{i, t}$ are centered to the (over-time and cross-country) mean to reduce multicollinearity between the interaction term and the crisis dummy. Based on equation (3), for each period $k$, the impact of banking crises on output is measured by: $\beta_{k}+$ $\delta^{k}\left(X_{i, t}-\bar{X}\right)$. This implies that, assuming $\beta_{k}<0$, the effect in absolute values is larger the lower is $\delta^{k}$.

Data for real GDP are taken from the World Bank Economic Indicators. Data for banking crises episodes are taken from Laeven and Valencia (2008a). In their paper the authors provide detailed information on the starting date of several banking, currency and debt crises. The dataset is constructed by combining quantitative indicators measuring banking sector distress, such as a sharp increase in non-performing loans and bank runs, with a subjective assessment of the situation. In particular, the database extends and builds on the Caprio, et al. (2005) banking crises database and covers the universe of systemic banking crises for the period 1970-2007. Data for crisis response strategies is based on the database built by Laeven and Valencia (2008b). The database documents many features of several banking crises episodes from 1980 to present,

\footnotetext{
${ }^{4}$ The choice of policy and structural variables is also influenced by data availability.
} 
including details on the resolution policy interventions put in place to attenuate the distress of the banking sector. The remaining data are taken from the IMF International Financial Statistics. ${ }^{5}$

\section{Results}

\subsection{Baseline}

We start by analyzing the estimated impact of banking crises on the real output as described in equation (1). The results for each period $k$ are displayed in Figure 1, together with the associated confidence bands. Looking at the figure it is immediately apparent that banking crises are associated with significant and long-lasting output losses. In particular, banking crises decrease real output by about 3 percent in the very short term ( 1 year after the occurrence of the crises), and by about 4.5 percent in the medium term ( 8 years after). In addition, similarly to Reinhart and Rogoff (2009) we find that the largest output losses occur around 3 years following the occurrence of a banking crisis.

To check for the robustness of our findings, we re-estimate equation (1) by alternatively including 1) a common time trend, 2) a country-specific time trend; and 3) oil shocks. The results remain statistically significant and almost unchanged (Figure 2a-2c).

As additional robustness check we re-estimate equation (1) using a 2-step GLS to control for serial autocorrelation and heteroskedasticity of the error terms. The results also in this case point to a statistically significant effect both in the short and in the medium term (Figure 2d).

Subsequently, we estimate equation 1 to test for the impact of currency and twin crises (currency and banking crises considered together). The results obtained are displayed respectively in Figure $3 \mathrm{a}$ and $3 \mathrm{~b}$. Looking at the figure we can observe that both currency and

\footnotetext{
${ }^{5}$ See Tables A1-A3 for detailed description and statistics.
} 
twin crises have a significant and sizeable impact on output in the short term, but in both cases output losses appear to revert in the medium term. In particular, 1 year after the occurrence of a currency (twin) crisis output lowers by almost 5 percent. In the medium term, however, the effect is close to zero and not statistically significant. This result is consistent with previous findings in the literature suggesting that banking crisis have more detrimental effects on the real economy in the medium term (Kaminsky and Reinhart, 1999; Goldstein et al., 2000; Cerra and Saxena, 2008).

\subsection{Structural Variables}

As a next step, we attempt to determine whether the effect of banking crises on developing countries' economic performance depends on their structural features. In particular, we test the role of country' size, openness, economic and financial development, and current account disequilibria.

Openness and Size

The output losses associated to banking crises can depend on economic size and trade openness for two opposite reasons. On the one hand, smaller and more open to trade economies are less diversified, tend to be more subject to idiosyncratic shocks (Rodrik, 1998) and are also characterized by lower automatic stabilizers (Alesina and Wacziard, 1999). On the other hand, fiscal stimulus packages put in place to soften the impact of crises tend to be less effective due to spillover effects. As a result, the effect of these variables on output losses remains uncertain (Cerra et al., 2009). Our findings seem to suggest that the two effects offset each other. In fact, 
both for size and trade openness the interaction term with the banking crises dummy is estimated to be not statistically significant ${ }^{6}$.

\section{Economic and Financial Development}

Subsequently, we consider the role of economic development, approximated by the GDP per-capita, in affecting output losses associated to banking crises. The results obtained estimating equation (2) are reported in Figure 4. The figure reports the estimated output losses in correspondence of three values of the GDP per capita: 1) the first quartile of the GDP per capita distribution; 2) the average (unconditional) response; and 3) the third quartile. Note that since the IRFs are plotted including only statistically significant results, the IRFs associated to the first and the third quartile will differ from the average (unconditional) effect only when the interaction term is statically significant.

Looking at the figure it seems that the initial impact of banking crises on output is a function of the economic development. More precisely, the short term effect of banking crises is almost three times larger in relatively more wealthy countries (corresponding to the third quartile) than in relative less wealthy countries (first quartile). This can be explained by the fact that in more economically developed countries the banking system is larger (Gurley and Shaw, 1967, Goldsmith, 1969, or Jung, 1986), and therefore a banking crisis may have more disruptive effects. ${ }^{7}$ This idea is confirmed by the results obtained estimating equation (2) using financial deepening as control and interaction term with the crises dummy. The results reported in Figure 5 (only when the interaction term is statistically significant) suggest that in countries with higher

\footnotetext{
${ }^{6}$ The results are not reported but they are available from the authors upon request.

7 In addition, as suggested by Bordo et al. (2001) financial development can increase banking instability by unsustainable credit expansion, deterioration of borrower capacity and balance sheet disequilibria.
} 
financial deepening (third quartile of the private credit-to-GDP ratio) output losses are twice larger than in countries with lower financial deepening (third quartile of the private credit-toGDP ratio). However, three years after the occurrence of the crises the output losses are the same for all developing countries irrespective of the degree of their financial deepening.

\section{Current Account Deficit}

Finally, we examine whether the impact of banking crisis on output performance depends on the level of the current account deficit. To this purpose we re-estimate equation (2) using current account deficit as control and interaction term with the crises dummy. The results from this estimation are displayed in Figure 6. As before, the figure shows the average response and the response corresponding to the first and third quartile of the current account deficit-to-GDP ratio only for interaction terms coefficients that are statistically significant. The results confirm that in the countries with greater external disequilibria output losses are larger in the short term. In particular in the first year, banking crisis reduces real output by about 4 percent in countries with higher current account disequilibria (third quartile), while in countries with smaller current account deficit (first quartile) the output loss is about 2 percent. However, after 2 years the size of current account deficit has no significant influence on output losses.

A possible explanation of both findings is the following. A country relying hardly on external financing is more vulnerable to banking crises in the short term due to sudden reversals in foreign capital flows. In the case of developing economies, this vulnerability is even more important given the presence of maturity and currency mismatches. However, after the initial detrimental impact, external disequilibria reverse and current account adjustments decrease the role of this factor in the propagation effects of banking crises to the real economy. 


\subsection{Policy Variables}

So far we have analyzed the structural heterogeneity of developing countries in explaining the effect of banking crises on economic performance. Now, we examine the effect of policy actions during the crises in reducing output losses. The variables taken into consideration are: fiscal and monetary policy, exchange rate regimes and banking intervention policies.

\section{Fiscal Policy}

First, we focus on the effect of banking crisis on real output controlling for fiscal policy actions. Other works (Cerra et al. 2009, Furceri and Zdzienicka, 2010) have investigated whether changes in government balances and government spending during crises have reduced output losses. However, a problem with this approach is that changes in government balances are clearly endogenous to output losses, via automatic stabilizers. To control for this problem we propose a measure of discretionary fiscal deficit. Following Fátas and Mihov $(2003,2006)$ and Afonso et al. (2010), we estimate discretionary fiscal measures using the following regression:

$\Delta d_{i, t}=\alpha+\beta \Delta d_{i, t-1}+\gamma \Delta y_{i, t}+\delta Z_{i, t}+\varepsilon_{i, t}$

Where $d$ represent government deficit, $y$ the (log of) real output and the estimated residuals $e_{i, t}$ will represent respectively our measures discretionary fiscal policy. In order to get these estimates, we include as control variables (i.e. the vector $Z$ ) the current and the lagged value of real oil prices, the current inflation rate and a linear time trend. Oil prices are included since they affect the state of the economy and more importantly because they contribute significantly to total revenue for some of the countries in the sample. We include inflation to ensure that our results are not driven by high inflation episodes. We also consider a time trend in our 
specifications, since government spending and revenue can also have a deterministic time trend in addition to the stochastic one. Finally, in order to control for possible endogeneity we use past values of real GDP as instruments.

To test whether discretionary fiscal policy during crises have significantly reduced output losses, we re-estimate equation (2) using our measure of discretionary fiscal policy as control and interaction term with the banking crises dummy. The results are reported in Figure 7. Looking at the figure, we notice that a discretionary increase in fiscal deficits reduced significantly the impact of banking crises both in the short and medium term. This result corroborate previous findings (Claessens et al., 2004; Cerra et al., 2009) and recommendations of international institutions (OECD, 2009; IMF, 2009).

\section{Monetary Policy}

In the case of monetary policy actions there is no unique recommendation during times of crises. This is due to the fact that the effect of monetary policy on the economic performance is uncertain during financial crises, especially for developing countries. On the one side, an increase in the interest rates can defend the domestic currency and attract foreign investors back into the country (Christiano et al., 2002). On the other side, a decrease in the interest rates can stimulate investment and economic growth.

To assess the effect of monetary policy actions during banking crises, we re-estimate equation (2) using the growth rate of money as control and interaction term. The results are displayed in Figure 8. Looking at the figure we can observe that, as for fiscal policy, also expansionary monetary policy has significantly contributed to reduce output losses. 


\section{Exchange Rate Regimes}

In this section we analyze whether output losses are bigger for countries with fixed or flexible exchange rate regimes. It is reasonable to think that under a flexible exchange rate regime, monetary authorities are less constrained and dispose of at least one additional policy instrument to deal with the crisis (Tong and Wei, 2009). Indeed, the estimation results reported in Figure 9 confirm the hypothesis that countries with flexible exchange rate regimes have generally performed better than countries with fixed exchange rates. In particular, in developing countries with flexible exchange rate regime the impact of banking crises on real output is below 1 percent in the short term, while for countries with fixed exchange rates this impact is about 2 percent. This difference is even more visible when we look at the banking crisis medium-term. Our results stay in line with the findings of Cerra et al. (2009) which suggest that countries with flexible exchange rates are characterized by a more rapid recovery. Banking Policy Interventions

This section analyzes the role of several banking crises resolution approaches: 1) Liquidity support; 2) Blanket guarantees; 3) Nationalization; 4) Recapitalization; and 5) Forbearance. These policies are usually adopted to restore public confidence in the financial sector and to restore the financial health of banking institutions. To test for the effectiveness of these variables we use the information collected in Laeven and Valencia (2008b), which describes the resolution policies adopted in a sample of 40 systemic banking crises episodes, to construct dummies for each resolution approach. Dummies take the value equal to 1 in correspondence of the adoption of the policy during a banking crisis and zero otherwise. ${ }^{8}$ Once these dummies variables are constructed we re-estimate equation (1) for each of the resolution

\footnotetext{
${ }^{8}$ See Table A1-3 for detailed statistics.
} 
policies. The results of this exercise are displayed in Figure 10. Looking at the figure it is evident that output losses differ according to the banking intervention policy adopted. In general, liquidity support resulted to be the policy associated with lower output losses, while blanket guarantees the policy associated with larger output losses. This difference is especially relevant in the long-term.

These results could have been driven by endogeneity bias, since it could be argued the adoption of given strategy it could be function of the observed or expected severity of the crises. ${ }^{9}$ However, when we test for endogeneity of banking intervention ${ }^{10}$ the results show the banking intervention policies adoption is not statically significantly affected by current or expected output $\operatorname{loss}^{11}$. Overall the results are in line with the finding of Detragiache and Ho (2010) which shows that strategies that commit fiscal resources (such as blanket guarantees, nationalization and recapitalization) do not lower the short term economic cost of the crises.

\section{Conclusions}

The main objective of this work was to provide new evidence of the effects of banking crises in developing countries, analyzing whether eventual output losses are permanent or if they are reverted in the medium term, and the role of structural and policy variables in affecting output losses.

\footnotetext{
${ }^{9}$ For example, using a different approach to assess output losses, Honohan and Klingebiel (2003) instrument liquidity support and government guarantees, and Detragiache and Ho (2010) construct an index of policy intervention which is instrumented by a measure of parliamentary system.

${ }^{10}$ We estimate a linear probability model of crises dummy against their lagged values and current and past output growth rates.

${ }^{11}$ The results are not reported but available from the authors upon request.
} 
In doing so, we studied the short and medium-term effect of banking crises on real output using an unbalanced panel of 159 developing countries over the period 1970-2006 and estimating impulse response functions of changes of real output to banking crises dummies.

Our main conclusions can be summarized as follows:

1) Banking crises significantly affect economic performance of developing countries lowering real output by about 3 percent in the short term (after 1 year) and by 4.5 percent in the medium term (after 8 years), with a peak effect reached three years after the occurrence of a banking crisis.

2) Output losses are larger for relatively more wealthy economies, characterized by a higher level of financial deepening and larger current account imbalances.

3) Flexible exchange rates, fiscal and monetary policy have been found to be efficient tools to soften the effect of the crises. Among banking intervention policies, liquidity support resulted to be the one associated with lower output losses. 


\section{References}

Afonso, A., Agnello, L. and Furceri, D. (2010). "Fiscal policy responsiveness, persistence and discretion", Public Choice (forthcoming).

Alesina, A., Wacziarg, R., (1998). "Openness, country size and government" 69(3), Journal of Public Economics, pp. 305-321.

Bordo, M., Eichengreen, B., Klingebiel, D., Soledad Martinez-Peria, M. (2001). 'Is the Crisis Problem Growing More Severe?', Economic Policy, 16(32), pp. 51-82.

Boyd J., Kwak, S., Smith, B. (2005). 'The Real Output Loss Associated with Modern Banking Crises', Journal of Money, Credit and Banking, 37, pp. 977-999.

Cai, X. and W.J. Den Haan, 2009, Predicting recoveries and the importance of using enough information, CEPR Working Paper 7508.

Calvo G. (2006). 'Monetary Policy Challenges in Emerging Markets: Sudden Stop, Liability Dollarization and Lender of Last Resort',. NBER Working Papers, 12788.

Calvo G., Reinhart, C. (2000). 'When Capital inflows come to a sudden stop: consequences and policy options', MPRA Papers 6982, University Library of Munich, Germany.

Caprio, G., D. Klingebiel, L. Laeven, and G. Noguera, 2005, "Appendix:Banking Crisis Database," in Patrick Honohan and Luc Laeven (eds.), Systemic Financial Crises: Containment and Resolution. Cambridge, U.K.: Cambridge University Press.

Cerra, V., Saxena, S. (2008). 'Growth Dynamics: The Myth of Economic Recovery', American Economic Review, 98, pp. 439-457.

Cerra V., Panizza, U., Saxena, S. (2009). 'International Evidence on Recovery from Recessions', IMF Working Paper 09/183.

Chang, R., Velasco, A. (1998). 'The Asian Liquidity Crisis’, NBER Working Paper 6796.

Claessens, C. A., Klingebiel, D., Laeven, L., (2004). "Resolving systemic financial crises: policies and institutions", Policy Research Working Paper Series 3377, The World Bank. 
Christiano, L., Gust, C., Roldos, J. (2002). "Monetary Policy in a Financial Crisis", NBER Working Papers, 9005.

Dell'Ariccia, G., Detragiache, E., Rajan, R. (2008). "The real effect of banking crises", Journal of Financial Intermediation, 17(1), pp. 89-112.

Deatragiache, E., G, Ho (2010) "Responding to Banking Crises: Lessons from Cross-Country Evidence", IMF Working Paper 10/18.

Fatás, A. and Mihov, I. (2003). “The Case for Restricting Fiscal Policy Discretion”, Quarterly Journal of Economics, 118, 1419-1447.

Fatás, A. and Mihov, I. (2006). “The Macroeconomics Effects of Fiscal Rules in the US States", Journal of Public Economics, 90, 101-117.

Furceri, D., Mourougane, A. (2009). "The effect of financial crises on potential output: New empirical evidence form OECD countries”, 699, OECD, Economics Department.

Furceri, D. Zdzienicka, A. (2010). "The Real Effects of Financial Crises in the European Transition Economies", forthcoming.

Goldstein, M., Kaminsky, G., Reinhart, C. (2000). Assessing Financial Vulnerability: An Early Warning System for Emerging Markets. Washington: Institute for International Economics.

Goldsmith, R. W. (1969), "Financial Structure and Development", New Haven, CT: Yale University Press.

Gurley J.G. and E. S. Shaw, (1955), "Financial Aspects of Economic Development" The American Economic Review, vol. 45 (4), 515-538

Honohan, P., Klingebiel, D. (2003). 'The Fiscal Cost Implication of an Accommodating Approach to Banking Crises', Journal of Banking and Finance, 27(8), pp. 1539-1560.

Hutchison, M. (2001). "How costly are IMF stabilization programs", Economic Letter, Federal Reserve Bank of San Francisco, issue Mar. 30 
Hutchison, M., Ilan, N., (2005). "How bad are twins? Output costs of currency and banking crises", Journal of Money, Credit and Banking, 37(4),pp. 725-752.

International Monetary Fund, World Economic Outlook (2009).

Jorda, O. (, 2005), “, Estimation and inference of impulse responses by local projections”, American Economic Review, vol. 95, no. 1, pp. 161-82.

Jung W.S. (1986), "Financial Development and Economic Growth: International Evidence", Economics Development and Cultural Change, vol. 34 (2), 333-346.

Kaminsky G., Reinhart, C. (1999). 'The Twin Crises. The Causes of Banking and Balance-ofPayments Problems', American Economic Review, 89, pp. 473-500.

Laeven L., Valencia, F. (2008a).'Systemic banking crises: a new database', IMF Working Paper, $\mathrm{WP} / 08 / 224$.

Laeven L., Valencia, F. (2008b). 'The use of blanket guarantess in banking crise', IMF Working Paper, WP/08/250.

Levy -Yeyati, E., Sturzenegger, F. (2005). 'Classifying Exchange Rate Regimes: Deeds vs. Words', European Economic Review, 49(6), pp. 1603-1635.

OECD Economic Outlook 86 (2009).

Reinhart, C., Rogoff, K. (2009). "The Aftermath of Financial crises”, NBER Working Papers, 14656.

Rodrik D. (1998). 'Why Do More Open Economies Have Bigger Governments?', Journal of Political Economy, 106(5), pp. 997-1032.

Romer, C., Romer, D. (1989). 'Does Monetary Policy Matter? A New Test in the Spirit of Friedman and Schwartz', NBER Macroeconomics Annual, 4: 121-170.

Teulings, C.N., and N. Zubanov (2009), "Economic recovery a myth? Robust estimation of impulse responses”, CPB Discussion Papers, November, 131. 


\section{Figure 1. The effect of banking crises on output}

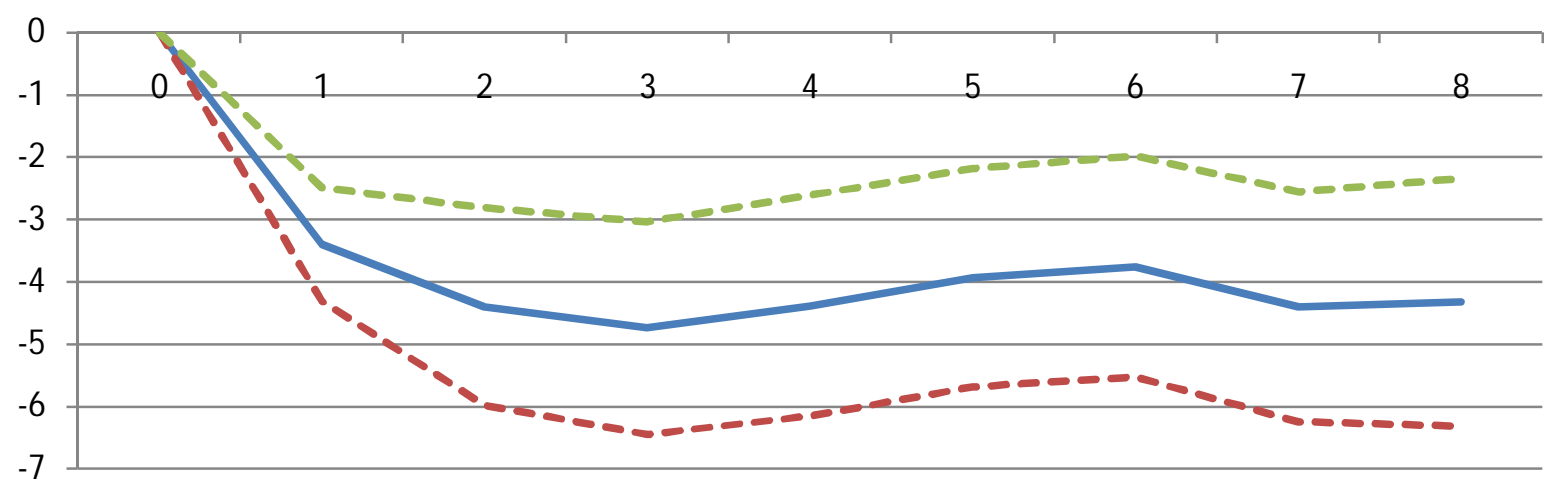

estimate $\quad-\infty$ lower limit $-\infty$ upper limit

Note: dotted lines represent 1 s.d. confidence bands.

\section{Figure 2.a Robustness test- Oil shocks}

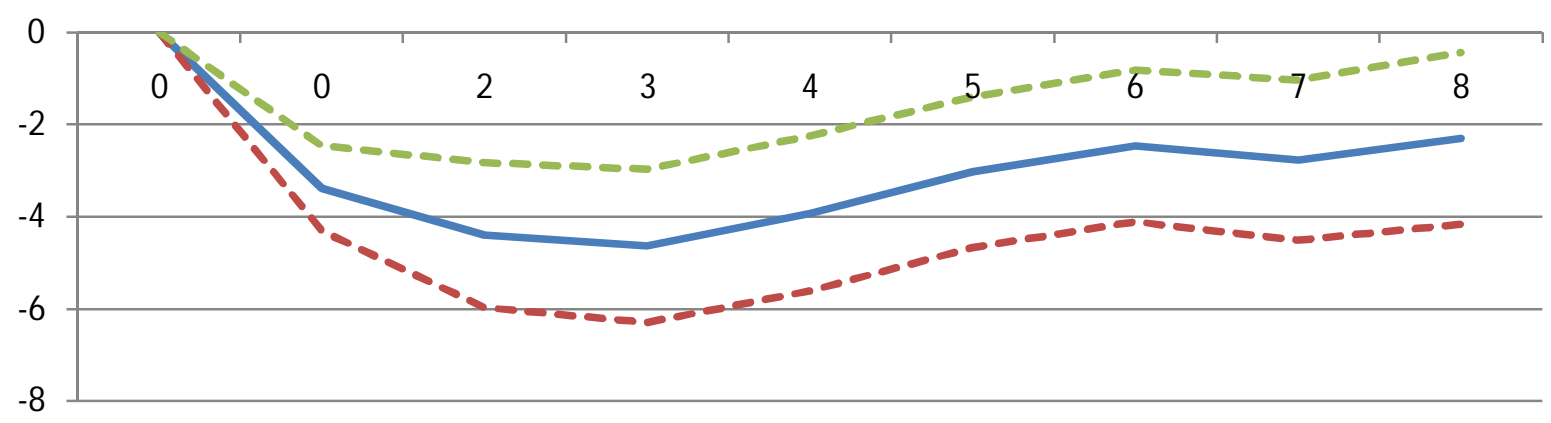

estimate $-\infty$ lower limit $-\infty$ upper limit

Note: dotted lines represent 1 s.d. confidence bands.

\section{Figure 2.b Robustness test- time trend}

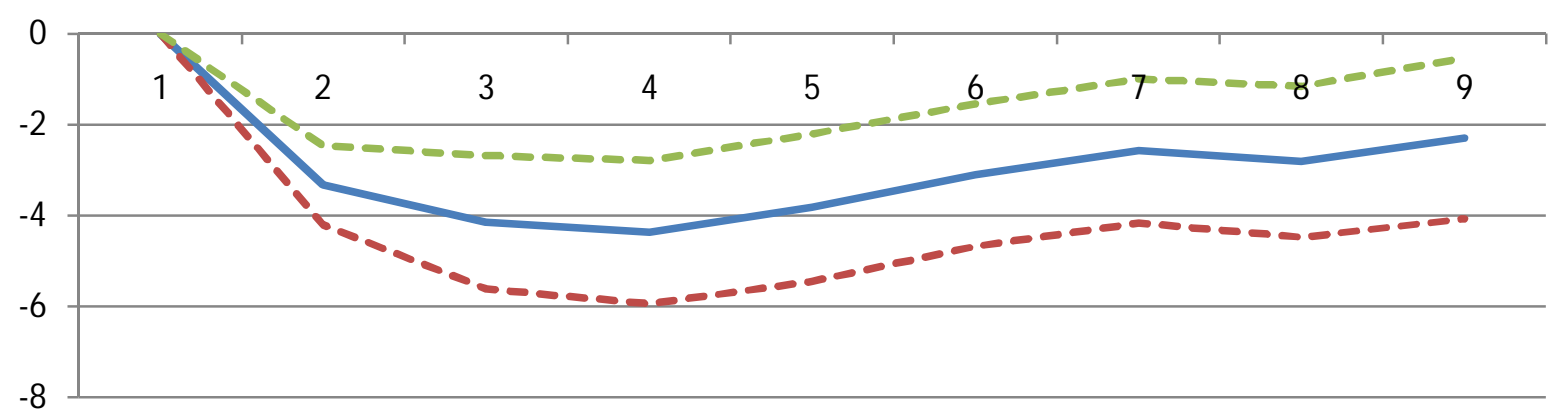

estimate $\quad-\infty$ lower limit $\quad-\infty$ upper limit

Note: dotted lines represent 1 s.d. confidence bands. 
Figure 2.c Robustness test- country specific time trend

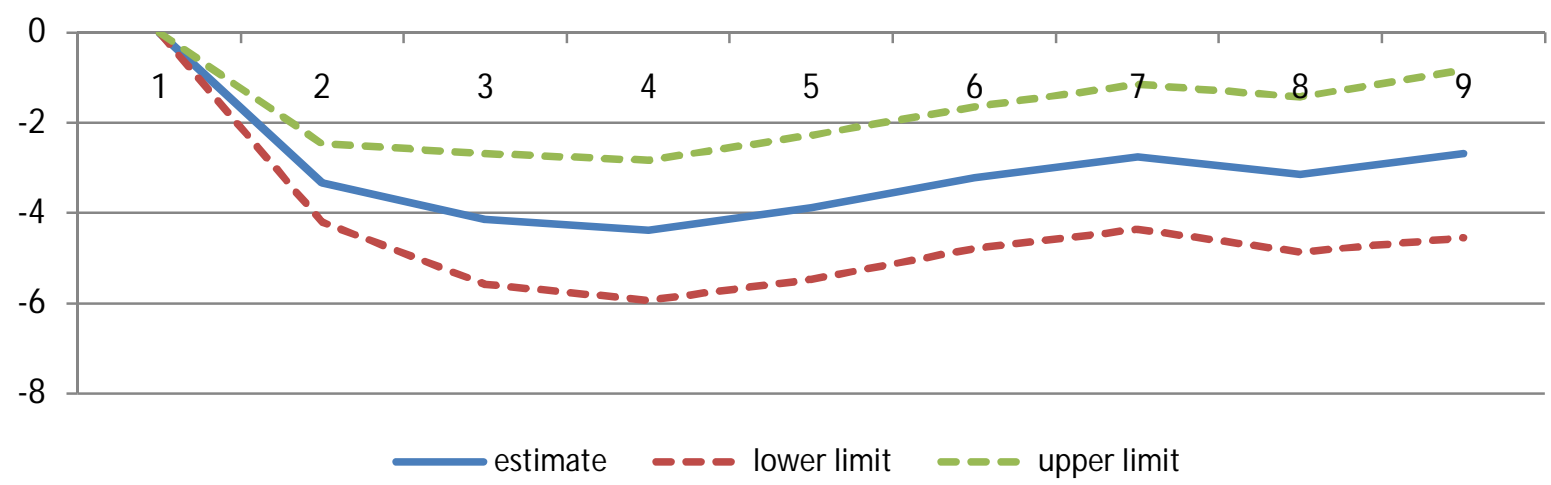

Note: dotted lines represent 1 s.d. confidence bands.

\section{Figure 2.d Robustness test- GLS}

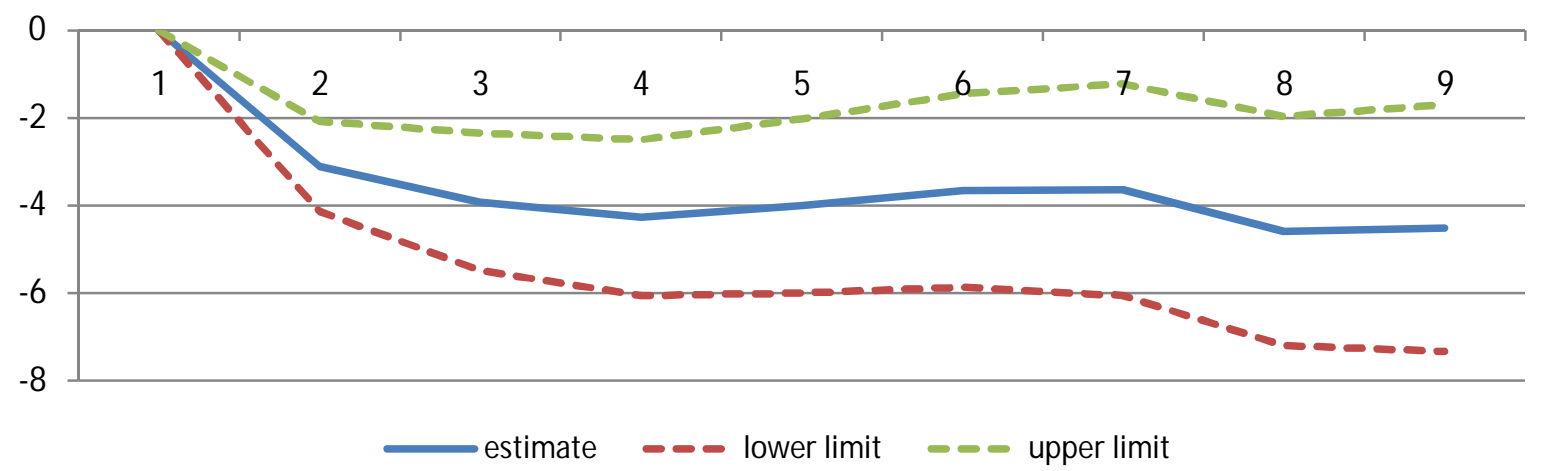

Note: dotted lines represent 1 s.d. confidence bands.

\section{Figure 3a. Currency Crises}

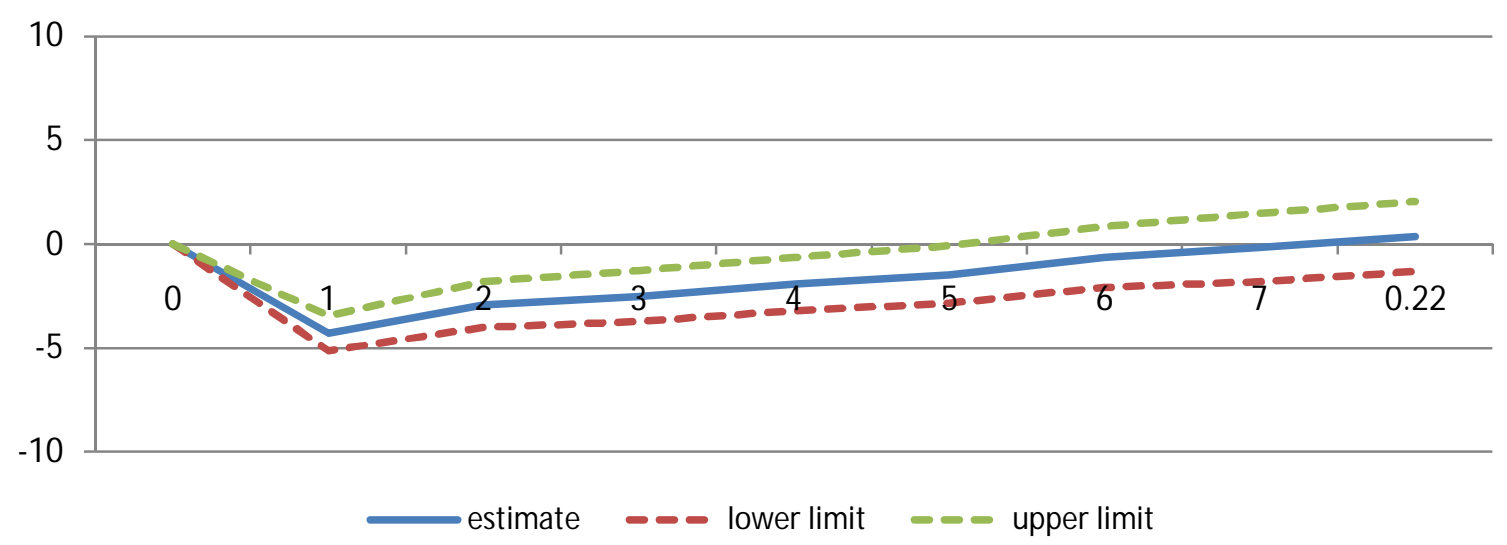

Note: dotted lines represent 1 s.d. confidence bands. 


\section{Figure 3b. Twin Crises}

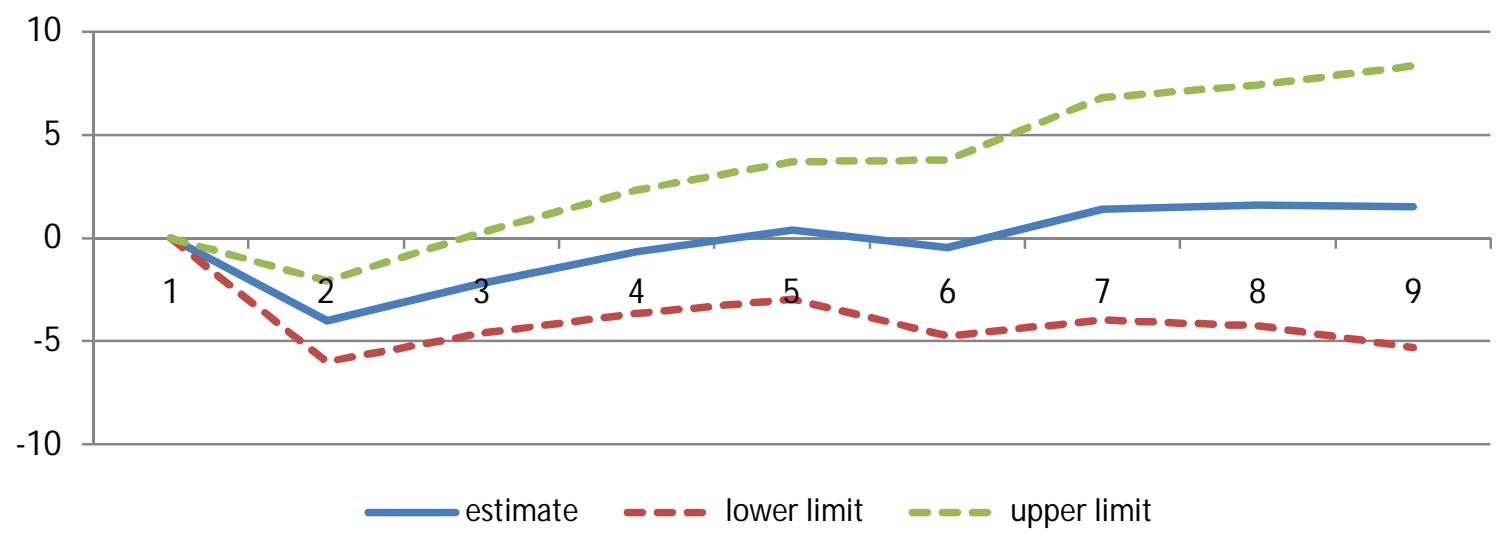

Note: dotted lines represent 1 s.d. confidence bands.

\section{Figure 4. The Impact Controlling for the Level of Economic Development}

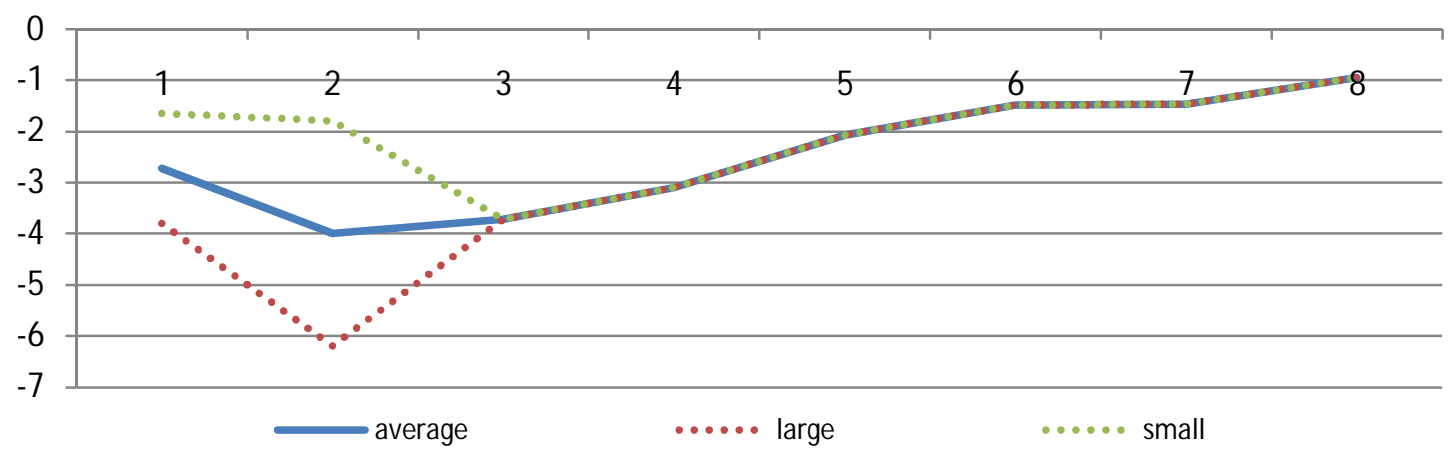

Note: Large and small identify the first and the third quartile of the GDP per capita distribution.

\section{Figure 5. The Impact Controlling Financial Deepening}

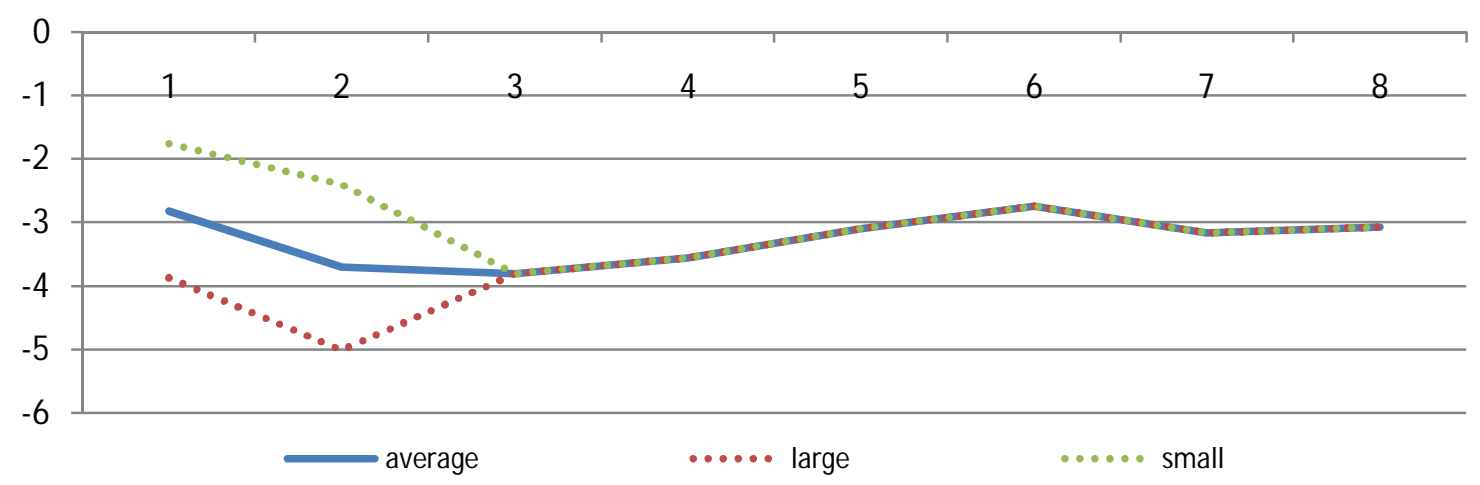

Note: Large and small identify the first and the third quartile of the Credit-GDP ratio distribution. 
Figure 6. The Impact Controlling for Current Account Imbalances

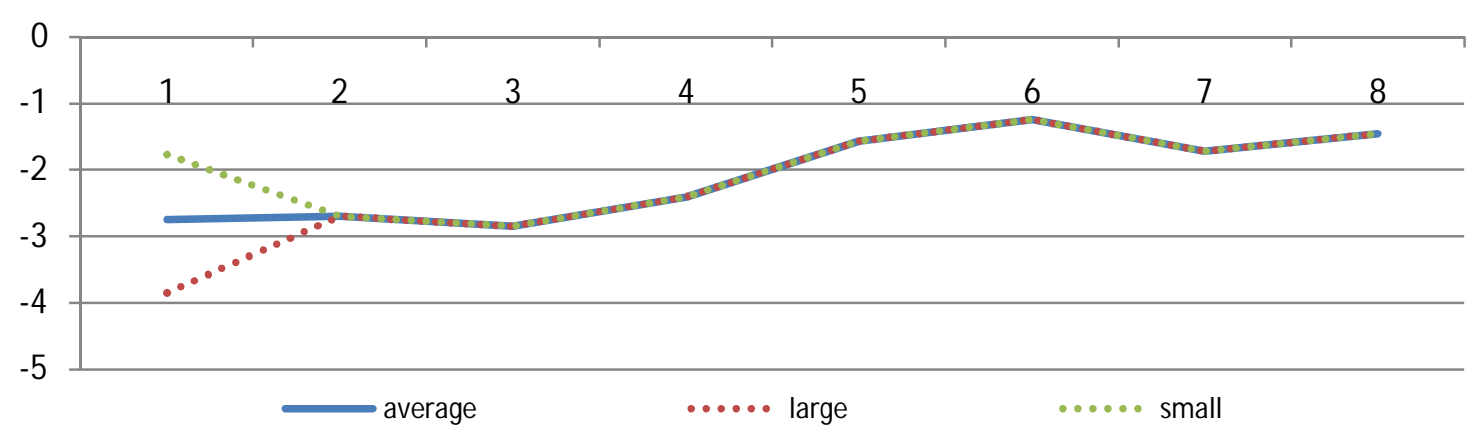

Note: Large and small identify the first and the third quartile of the Current Account Deficit-GDP ratio distribution.

\section{Figure 7. The Impact Controlling for Discretionary Fiscal Policy}

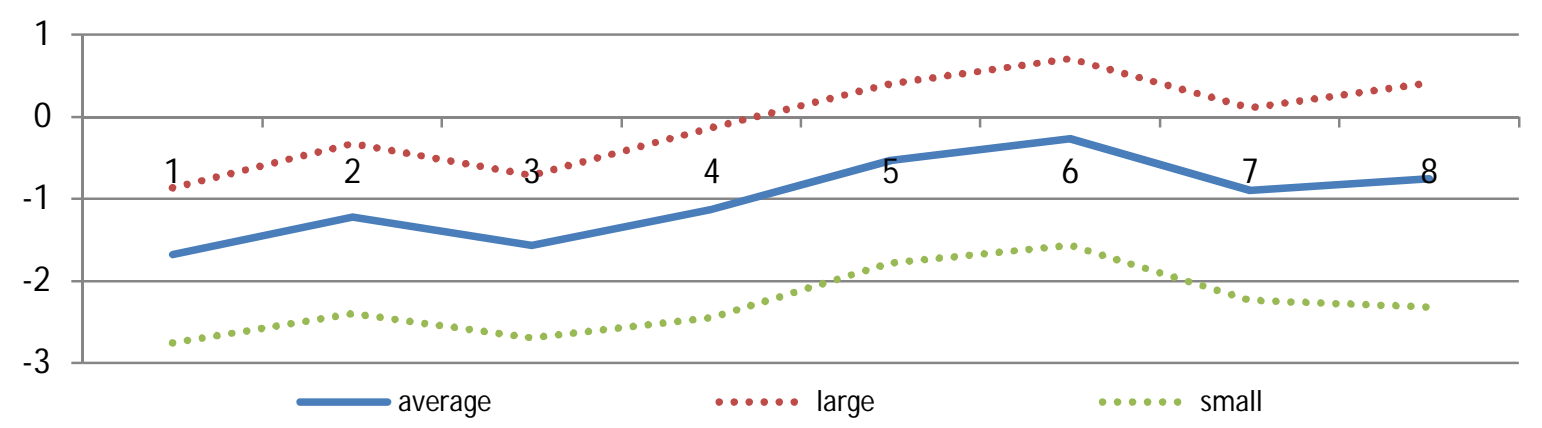

Note: Large and small identify the first and the third quartile of the discretionary public deficits distribution.

\section{Figure 8. The Impact Controlling for Monetary Policy}

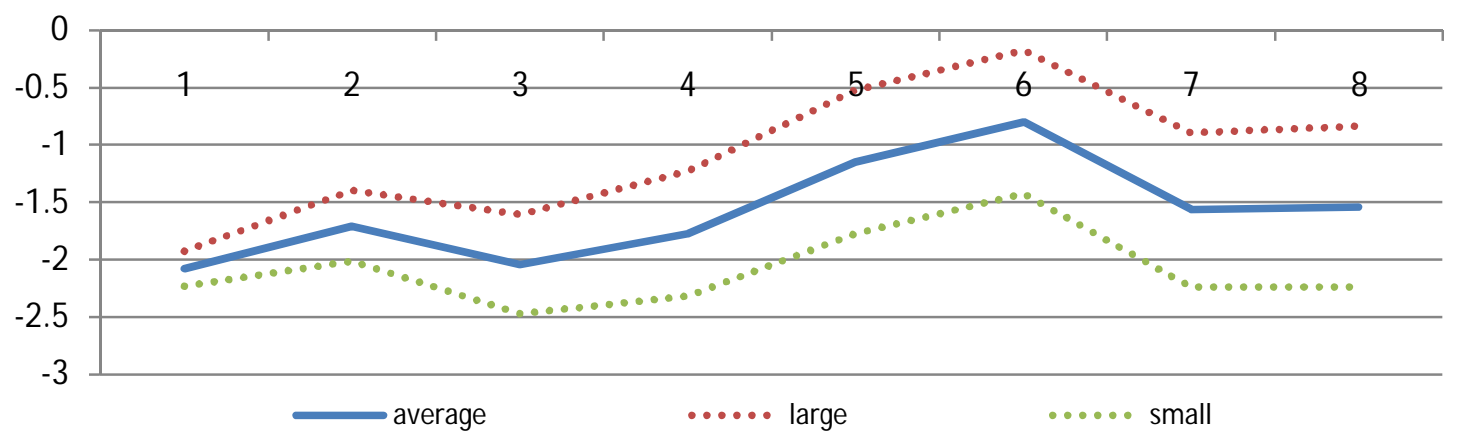

Note: Large and small identify the first and the third quartile of the money growth distribution. 
Figure 9. The Impact Controlling for Exchange Rate Regimes

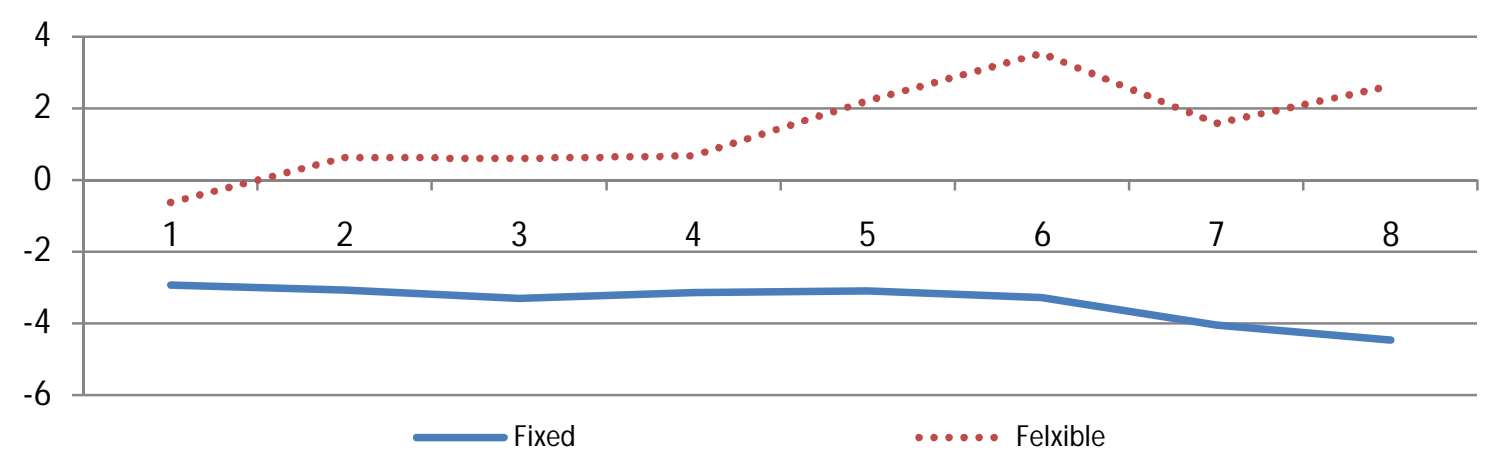

Figure 10. The Impact Controlling for Bank Intervention Policies

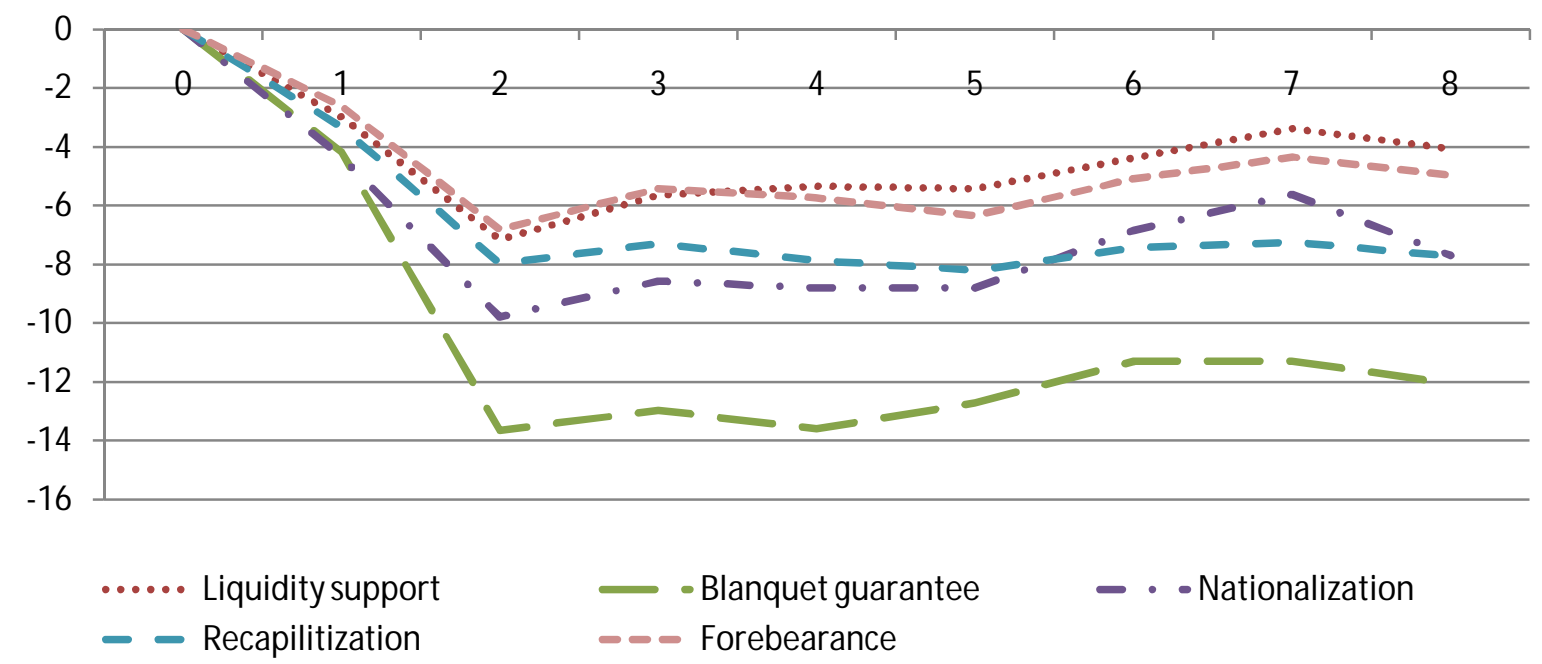




\section{Appendix}

Table A1. Banking Crises Episodes

\begin{tabular}{|c|c|c|c|c|c|}
\hline Albania & 1994 & Djibouti & 1991 & Nepal & 1988 \\
\hline Algeria & 1990 & Dominican Republic & 2003 & Nicaragua & 1990 \\
\hline Argentina & 1980 & Ecuador & 1982 & Nicaragua & 2000 \\
\hline Argentina & 1989 & Ecuador & 1998 & Niger & 1983 \\
\hline Argentina & 1995 & Egypt, Arab Rep. & 1980 & Nigeria & 1991 \\
\hline Argentina & 2001 & El Salvador & 1989 & Panama & 1988 \\
\hline Armenia & 1994 & Equatorial Guinea & 1983 & Paraguay & 1995 \\
\hline Azerbaijan & 1995 & Eritrea & 1993 & Peru & 1983 \\
\hline Bangladesh & 1987 & Estonia & 1992 & Philippines & 1983 \\
\hline Belarus & 1995 & Georgia & 1991 & Philippines & 1997 \\
\hline Benin & 1988 & Ghana & 1982 & Poland & 1992 \\
\hline Bolivia & 1986 & Guinea & 1985 & Romania & 1990 \\
\hline Bolivia & 1994 & Guinea & 1993 & Russian Federation & 1998 \\
\hline Bosnia and Herzegovina & 1992 & Guinea-Bissau & 1995 & Sao Tome \& Principe & 1992 \\
\hline Brazil & 1990 & Guyana & 1993 & Senegal & 1988 \\
\hline Brazil & 1994 & Haiti & 1994 & Sierra Leone & 1990 \\
\hline Bulgaria & 1996 & Hungary & 1991 & Slovak Republic & 1998 \\
\hline Burkina Faso & 1990 & India & 1993 & Slovenia & 1992 \\
\hline Burundi & 1994 & Indonesia & 1997 & Sri Lanka & 1989 \\
\hline Cameroon & 1987 & Israel & 1977 & Swaziland & 1995 \\
\hline Cameroon & 1995 & Jamaica & 1996 & Tanzania & 1987 \\
\hline Cape Verde & 1993 & Jordan & 1989 & Thailand & 1983 \\
\hline Central African Republic & 1976 & Kenya & 1985 & Thailand & 1997 \\
\hline Central African Republic & 1995 & Kenya & 1992 & Togo & 1993 \\
\hline Chad & 1983 & Korea, Rep. & 1997 & Tunisia & 1991 \\
\hline Chad & 1992 & Kuwait & 1982 & Turkey & 1982 \\
\hline Chile & 1976 & Kyrgyz Republic & 1995 & Turkey & 2000 \\
\hline Chile & 1981 & Latvia & 1995 & Uganda & 1994 \\
\hline China & 1998 & Lebanon & 1990 & Ukraine & 1998 \\
\hline Colombia & 1982 & Liberia & 1991 & Uruguay & 1981 \\
\hline Colombia & 1998 & Lithuania & 1995 & Uruguay & 2002 \\
\hline Congo, Dem. Rep. & 1983 & Macedonia, FYR & 1993 & Venezuela, RB & 1994 \\
\hline Congo, Dem. Rep. & 1991 & Madagascar & 1988 & Vietnam & 1997 \\
\hline Congo, Dem. Rep. & 1994 & Malaysia & 1997 & Yemen, Rep. & 1996 \\
\hline Congo, Rep. & 1992 & Mali & 1987 & Zambia & 1995 \\
\hline Costa Rica & 1987 & Mauritania & 1984 & Zimbabwe & 1995 \\
\hline Costa Rica & 1994 & Mexico & 1981 & & \\
\hline Cote d'Ivoire & 1988 & Mexico & 1994 & & \\
\hline Croatia & 1998 & Morocco & 1980 & & \\
\hline Czech Republic & 1996 & Mozambique & 1987 & & \\
\hline
\end{tabular}


Table A2. Banking Resolution Policies

\begin{tabular}{|c|c|c|c|c|c|c|}
\hline Country & Year & $\begin{array}{c}\text { Blanket } \\
\text { Guarantees }\end{array}$ & $\begin{array}{r}\text { Liquidity } \\
\text { Support } \\
\end{array}$ & Forbearance & Nationalization & Recapitalization \\
\hline Argentina & 1980 & 0 & 1 & 1 & 1 & 0 \\
\hline Argentina & 1989 & 0 & 1 & 0 & 0 & 0 \\
\hline Argentina & 1995 & 0 & 0 & 0 & 0 & 1 \\
\hline Argentina & 2001 & 0 & 1 & 1 & 1 & 1 \\
\hline Bolivia & 1994 & 0 & 1 & 1 & 0 & 1 \\
\hline Brazil & 1990 & 0 & 1 & 0 & 0 & 0 \\
\hline Brazil & 1994 & 0 & 1 & 1 & 0 & 1 \\
\hline Bulgaria & 1996 & 0 & 1 & 1 & 1 & 1 \\
\hline Chile & 1981 & 0 & 1 & 1 & 0 & 1 \\
\hline Colombia & 1982 & 0 & 1 & 0 & 1 & 1 \\
\hline Colombia & 1998 & 0 & 1 & 1 & 1 & 1 \\
\hline Cote d'Ivoire & 1988 & 0 & 1 & 1 & 0 & 1 \\
\hline Croatia & 1998 & 0 & 0 & 1 & 1 & 1 \\
\hline Czech Rep. & 1996 & 0 & 0 & 0 & 0 & 1 \\
\hline Dominican Rep. & 2003 & 0 & 1 & 1 & 0 & 0 \\
\hline Ecuador & 1998 & 1 & 1 & 1 & 1 & 1 \\
\hline Estonia & 1992 & 0 & 1 & 1 & 1 & 1 \\
\hline Ghana & 1982 & 0 & 0 & 1 & 0 & 1 \\
\hline Indonesia & 1997 & 1 & 1 & 1 & 1 & 1 \\
\hline Jamaica & 1996 & 1 & 1 & 0 & 1 & 1 \\
\hline Korea, Rep. & 1997 & 1 & 1 & 1 & 1 & 1 \\
\hline Latvia & 1995 & 0 & 0 & 0 & 0 & 0 \\
\hline Lithuania & 1995 & 0 & 0 & 1 & 1 & 1 \\
\hline Malaysia & 1997 & 1 & 1 & 1 & 1 & 1 \\
\hline Mexico & 1994 & 1 & 1 & 1 & 1 & 1 \\
\hline Nicaragua & 1990 & 1 & 1 & 0 & 0 & 0 \\
\hline Paraguay & 1995 & 0 & 1 & 1 & 0 & 1 \\
\hline Philippines & 1997 & 0 & 0 & 0 & 0 & 0 \\
\hline Russian Fed. & 1998 & 0 & 1 & 1 & 1 & 0 \\
\hline Sri Lanka & 1989 & 0 & 0 & 1 & 0 & 1 \\
\hline Thailand & 1997 & 1 & 1 & 1 & 1 & 1 \\
\hline Turkey & 2000 & 1 & 1 & 0 & 1 & 1 \\
\hline Ukraine & 1998 & 0 & 1 & 1 & 0 & 0 \\
\hline Uruguay & 2002 & 1 & 0 & 0 & 1 & 1 \\
\hline Venezuela & 1994 & 0 & 1 & 1 & 1 & 1 \\
\hline Vietnam & 1997 & 0 & 0 & 1 & 0 & 1 \\
\hline
\end{tabular}


Table A3. Descriptive Statistics

\begin{tabular}{lccc}
\hline Variable & Observations & Mean & Std. Dev. \\
\hline Real GDP (log) & 5878 & 22.447 & 2.058 \\
Openness & 4135 & 0.800 & 0.548 \\
Population (log) & 4172 & 1.522 & 2.017 \\
GDP (log, USD) & 4175 & 1.868 & 2.136 \\
Real GDP per capita (log, USD) & 5867 & 7.232 & 1.384 \\
Banking Credit to Private Sector (\%, GDP) & 3943 & 0.288 & 0.260 \\
Current Account Balance (\%, GDP) & 3876 & -4.106 & 11.329 \\
Foreign Direct Investment (\%, GDP) & 4146 & -24.820 & 220.636 \\
Government Deficit (\%, GDP) & 3587 & 3.772 & 8.526 \\
Broad Money Growth (\%) & 3676 & 22.218 & 37.377 \\
\hline
\end{tabular}

